\title{
EDITORIAL
}

\section{Crónica de una decepción anunciada ó la cumbre de Copenhague}

Uno de los aspectos ambientales más sorprendentes de la historia de nuestro planeta es la constancia de la temperatura superficial. Las pruebas geológicas sugieren que esa temperatura media no ha variado más allá de los límites entre 7 y $27^{\circ} \mathrm{C}$, lo que ha jugado un papel de transcendental importancia al ser determinante para el estado del agua. Esos valores medios no solo dependen de la temperatura efectiva, sino también del efecto invernadero, que atrapa el calor que de otra forma se radiaría hacia el espacio, y esto a su vez es función del tipo de gases que haya en la atmósfera y de las cantidades de cada uno de ellos. Esos procesos han asegurado que la Tierra se haya mantenido, de forma global, con temperaturas medias cercanas a los $17^{\circ} \mathrm{C}$.

La manera en que la temperatura de la Tierra parece realmente haber evitado los extremos de frío y calor, sugirió a Lovelock y Margulis, a través de su teoría Gaia, que la vida ha jugado un papel transcendental en los procesos de retroalimentación que regulan la temperatura, partiendo de dos premisas fundamentales: la vida únicamente existe porque las condiciones ambientales del planeta son las adecuadas para su existencia; y al mismo tiempo la propia vida define las condiciones naturales necesarias para su supervivencia y trata de asegurar su mantenimiento.

Efectivamente, la vida se ha mantenido en un extraordinario esfuerzo de equilibrio dinámico durante cientos de millones de años. Si la temperatura, humedad, salinidad, acidez o cualquier otra característica ambiental se hubiera salido significativamente de un estrecho margen de valores, la vida como fenómeno global de este planeta habría corrido un riesgo muy elevado de aniquilamiento. Ha encontrado, de alguna forma, la manera de forzar las condiciones para moverse en el margen permitido. Y así ha salido con éxito de periodos de glaciaciones o de sobrecalentamiento extremo, por efecto invernadero fugitivo, producido por la presencia de gases de alto poder de retención de calor, como el amoniaco. En cualquiera de los cálculos habría que introducir el efecto de mecanismos de defensa que la vida utiliza para protegerse a sí misma.

Pero la aparición del hombre sobre el planeta cambia la escala temporal relativa de la proyección evolutiva. Con anterioridad al hombre todos los acontecimientos habían ocurrido a ritmos prácticamente imperceptibles, comparados con el concepto de tiempo medido a escala humana. Como señalaba el Prof. Margalef, todas las preocupaciones de hoy día hicieron su 
aparición cuando el hombre empezó a jugar con demasiado entusiasmo con sus útiles y ensayó nuevos sistemas de vida. En la historia humana la acción tiene lugar cuando se pasa de la regulación local a la regulación global, y precisamente ahora nos encontramos en los últimos estadíos de ese proceso, en los que la especie humana consigue el control sobre muchos ecosistemas combinados, desarrollando para ello un mecanismo que es más cultural que genético.

Una de las características más sorprendentes de la especie humana queda definida por el notable despilfarro de cualquier forma de energía, fundamentalmente para mantener un metabolismo externo cada vez más elevado y que se manifiesta de una manera mucho más ostensible que en el resto de los organismos. Para cubrir esas necesidades creadas, el hombre utiliza grandes cantidades de energía fósil y su degradación última se transforma en graves problemas de contaminación que están alterando, en un periodo de tiempo relativamente muy corto, el equilibrio estructural y funcional del planeta.

La investigación realizada a nivel global, por un gran número de científicos durante las últimas décadas, ha puesto en evidencia una serie de cambios climáticos en todo el planeta. Aún no se sabe cuánto tardarán en concretarse ni cuál será la gravedad del problema, pero no resulta fácil poner freno a esos cambios. Una cosa sí está clara, que una vez producida la alteración climática, la vuelta a la normalidad, si es que puede conseguirse, llevará siglos. Y eso siempre y cuando se detengan las causas de tales alteraciones, o al menos se ralenticen los procesos que las producen.

$\mathrm{Al}$ aumentar la concentración de gases con efecto invernadero, se absorbe en las capas inferiores de la atmósfera una mayor cantidad de radiación infrarroja que, de lo contrario, se habría perdido en el espacio, y se altera el balance de radiaciones de la Tierra. La concentración de la mayoría de gases responsables del efecto invernadero, y en especial de dióxido de carbono, ha venido aumentando de forma continuada durante el siglo pasado, demostrando que las emisiones antropogénicas han excedido la capacidad natural de eliminación de estos gases, ya sea mediante su absorción por las superficies terrestres, por los océanos o mediante reacciones químicas en la atmósfera. El aumento desde la era industrial, en términos de radiación, equivale a un incremento aproximado del $50 \%$ de dióxido de carbono.

La especie humana tiene algo muy importante que la diferencia de las demás. Ha conseguido una capacidad mental y un nivel de conciencia únicos, más altos que cualquier otra. El hombre posee tanto atributos biológicos como culturales y estos últimos se han conseguido como un paso por encima de la evolución biológica, aunque ambos coexisten en el tiempo interactuando entre 
sí. Esas capacidades que le han permitido una evolución tan rápida son las que ahora le fuerzan a tomar una conciencia de su entorno, de su pasado y de su futuro.

Conscientes de los cambios, se pone en marcha un proceso, igualmente global, para plantear una solución que de no ser lo suficientemente urgente y ágil puede acabar con las condiciones del delicado equilibrio de nuestro planeta. Poco más de un siglo, en una historia que se cuenta en miles de millones de años, ha sido suficiente para que la especie que consiguió los niveles más altos de la evolución y el desarrollo sea ahora incapaz de darse cuenta que depende total y absolutamente de esas mismas condiciones. Después de tener una idea clara del problema, y de reunir pruebas científicas que ponen de manifiesto cuáles son y cuáles pueden ser las consecuencias de tales alteraciones y cambios, sigue olvidando los orígenes biológicos a los que la evolución llegó a encumbrarle.

El Convenio Marco de las Naciones Unidas sobre el Cambio Climático tenía como objetivo lograr la estabilización de las concentraciones de gases de efecto invernadero en la atmósfera a un nivel que impida interferencias antropógenas peligrosas en el sistema climático, resaltando que dicho nivel debería alcanzarse en un plazo suficiente para permitir la adaptación natural de los ecosistemas, asegurar que la producción de alimentos no se vea amenazada y permitir un desarrollo económico sostenible. Desde 1995, con la reunión de carácter internacional de Berlín, se ha pretendido llegar a un acuerdo satisfactorio, llegando incluso a propuestas de compromiso, aunque no de todos los países ni los más importantes, como las referencias marcadas en la Cumbre de Kyoto de 1997, con indicaciones válidas en una primera proyección que debería tener cumplidos sus objetivos para el 2012. Pero han pasado, una tras otra, reuniones para recordar, matizar, puntualizar y evidenciar, poniendo al fin la mirada y las esperanzas en la Cumbre de Copenhague, que debería concretar la respuesta unánime y tajante de todos los países para asegurar el futuro equilibrado del planeta. Sin embargo la respuesta ha pecado de individualismo y egoísmo, con compromisos desdibujados, pacatos y faltos de solidaridad. Tras las disculpas se fijan los deberes para la próxima vez, pero quizá para mañana ya sea demasiado tarde.

Estanislao de Luis Calabuig 